\title{
Czy radioterapia u chorych na raka piersi po operacji oszczędzającej może być jeszcze krótsza, niż obecnie zalecana?
}

\author{
Can radiotherapy following breast conserving surgery \\ be even shorter than actually recommended?
}

\section{Szanowny Panie Redaktorze!}

Minęło właśnie 25 lat, kiedy po powrocie z rocznego stażu w Christie Hospital w Menczesterze wspólnie z profesorem A. Hliniakiem podjęliśmy wyzwanie wprowadzenia hipofrakcjonowanej radioterapii u chorych na raka piersi po operacji oszczędzającej. W tym czasie mówienie o dawce frakcyjnej większej od 2 Gy i napromienianiu krótszym niż 5 tygodni w większości ośrodków radioterapeutycznych na świecie, w tym także w Polsce, stanowiło herezję. Jednakże już od II wojny światowej niektóre ośrodki brytyjskie i kanadyjskie stosowały 15 dawek frakcyjnych po 2,7 Gy przez 3 tygodnie z dobrym efektem klinicznym. W ostatnich 10 latach stwierdzono, że współczynnik $\alpha / \beta$ dla raka piersi jest podobnie niski jak dla późno reagujących zdrowych tkanek piersi, i wynosi około 4 Gy [1]. W związku z tym zaakceptowano fakt, że niewielkie podwyższenie dawki frakcyjnej i obniżenie całkowitej nie zmieni indeksu terapeutycznego, tzn. nie wpłynie na pogorszenie wyleczenia miejscowego i/lub nie zwiększy ryzyka późnych powikłań. Uznano również, że skrócenie czasu leczenia może przyczynić się do zwiększenia skuteczności miejscowej, gdyż przy 5-tygodniowej lub dłuższej radioterapii 0,6 Gy dawki dziennej jest „tracona” na kompensację repopulacji komórek nowotworowych [2]. W wielu badaniach z randomizacją z ponad 10-letnimi obserwacjami potwierdzono równorzędną skuteczność i toksyczność napromienia skróconego metodą hipofrakcjonacji i standardowej radioterapii (badania: START A i B, RMH/GOC, ONTARIO) [3-6]. Na ostatniej Konferencji wSt. Gallen, dotyczącej leczenia uzupełniającego wczesnego raka piersi, uznano, że skrócone do 3-4 tygodni schematy radioterapii pooperacyjnej powinny stanowić standard postępowania [7]. W Centrum Onkologii w Warszawie, jak i w wielu ośrodkach radioterapii w Polsce czterotygodniowy schemat napromieniania pooperacyjnego na całą pierś wprowadzono do rutynowego stosowania w 2005 roku, po zakończonym sukcesem, sponsorowanym przez Komitet Badań Naukowych krajowym, wieloośrodkowym badaniu populacyjnym [8]. Jednakże wiadomo, że z powodu zwiększonego ryzyka wznowy w loży pooperacyjnej dawka w tej okolicy powinna być podwyższana. Jest to tzw. boost. Wysokość dawki boostu zależy od wielu czynników klinicznych i patologicznych [9]. W związku z obawą przed wysokimi frakcjami boost na lożę pooperacyjną stosowany jest w większości przypadków metodą sekwencyjną po zakończeniu 4-5-tygodniowego napromieniania całej piersi. Przedłuża to napromienianie o kolejne 1-2 tygodnie. Obecnie dane kliniczne wskazują na możliwość podawania nie tylko nieco wyższych dawek frakcyjnych na całą pierś, ale także na jednoczasowe podwyższanie dawki na lożę po tumorektomii. Od około 10 lat wraz z rozwojem techniki radioterapii z modulowaniem intensywnością dawki (IMRT — intensity modulated radiotherapy) podjęto badania nad zastąpieniem boostu sekwencyjnego boostem integracyjnym (SIB - simultaneous integrated boost). Metoda ta polega na podawaniu jednoczasowo z napromienianiem całej piersi zwiększonej dawki na lożę pooperacyjną. Stwierdzono, że techniką trójwymiarowej konformalnej radioterapii (3D-CRT) z jednoczasowym boostem również można, w większości przypadków, uzyskać prawidłowe rozkłady dawek. Wykazano jednakże wyższość techniki IMRT nad 3D-CRT w niektórych nietypowych przypadkach. W innych badaniach stwierdzono, że stosując technikę 3D-CRT, można łączyć 4-tygodniową hipofrakcjonowaną radioterapię z boostem jednoczasowym, nie zwiększając toksyczności miejscowej [10-12]. Dane z piśmiennictwa wskazują na dobrą tolerancję 4-tygodniowego napromieniania techniką SIB i porównywalnymi do konwencjonalnego napromieniania: efektem kosmetycznym, ryzykiem późnych powikłań i wznów miejscowych w czasie 5-letniej obserwacji [13-15]. Istnieją wprawdzie inne metody podwyższania dawki na obszar loży po tumorektomii, jak $\mathrm{np}$. śródoperacyjna brachyterapia czy elektronoterapia, ale wymagają one i tak drugiego etapu napromieniania całej piersi, którego rozpoczęcie wielokrotnie z różnych przyczyn, np. wieloetapowego działania chirurgicznego, może ulec 
niepotrzebnemu wydłużeniu. Z tego punktu widzenia jednoetapowe napromienianie omawianą techniką SIB wydaje się najbardziej korzystną metodą leczenia.

W związku z powyższymi argumentami i danymi z piśmiennictwa w ubiegłym roku w Centrum Onkologii w Warszawie na Ursynowie wprowadzono napromienianie chorych po operacji oszczędzającej metodą SIB, techniką 3D-CRT lub — w szczególnych przypadkach — techniką IMRT. Na okolicę całej piersi podawana jest dawka dzienna 2,25 Gy z jednoczasowym podwyższeniem dawki na lożę od 2,7 do 2,8 Gy, w czasie 4 tygodni dawka całkowita w całej piersi wynosi 45 Gy, zaś w loży — od 54 do 56 Gy. Dotychczas metodą SIB leczono około 100 chorych. Wstępna ocena tolerancji napromieniania i wczesnych odczynów popromiennych wskazuje, że są one podobne do obserwowanych uprzednio przy stosowaniu leczenia z boostem sekwencyjnym. Uważam, że napromienianie pooperacyjne metodą czterotygodniową z jednoczasowym boostem powinno być rozważane jako leczenie standardowe. Musi być jednak stosowane w ścisłej współpracy z zespołem fizyków medycznych, w specjalistycznych ośrodkach dysponujących odpowiednią aparaturą do precyzyjnej weryfikacji obszarów napromienianych. Zastosowanie tej techniki powoduje skrócenie napromieniania od 1 do 2 tygodni, co sprawia, że jest ona mniej uciążliwa dla chorych. Poza tym skrócenie czasu napromieniania tej dość licznej grupy, stanowiącej około $20 \%$ chorych napromienianych w zakładach radioterapii, zmniejsza obciążenie akceleratorów i zwalnia miejsca dla innych chorych.

\section{Dr n. med. Jacek Gałeck}

Zakład Radioterapii

Centrum Onkologii — Instytut

im. Marii Skłodowskiej-Curie w Warszawie

e-mail:jacekgg@poczta.fm

\section{Piśmiennictwo}

1. Scorsetti M, Alongi F, Fogliata A i wsp. Phase I-II study of hypofractionated simultaneous integrated boost using volumetric modulated arc therapy for adjuvant radiation therapy in breast cancer patients: a report of feasibility and early toxicity results in the first 50 treatments. Radiation Oncology 2012; 7: 145. doi.10.1186/1748-717X-7-145.

2. Yarnold J, Haviland J, Bentzen SM i wsp. Estimation of an overall treatment time factor for local relapse after adjuvant radiotherapy for early breast cancer by the UK START Trialists' Group. Eur J Cancer 2013; 49 (Suppl. 2): S405.

3. Bentzen SM, Agrawal RK, Aird EG i wsp.The UK Standardisation of Breast Radiotherapy (START) Trial A of radiotherapy hypofractionation for treatment of early breast cancer: a randomised trial. Lancet Oncol 2008; 9: 331-341.

4. Bentzen SM, Agrawal RK, Aird EG i wsp. The UK Standardisation of Breast Radiotherapy (START) Trial B of radiotherapy hypofractionation for treatment of early breast cancer: a randomised trial. Lancet 2008; 371: 1098-1107.

5. Owen JR, Ashton A, Bliss JM i wsp. Effect of radiotherapy fraction size on tumour control in patients with early-stage breast cancer after local tumour excision: long term results of a randomised trial. Lancet Oncol 2006; 7: 467-471.

6. Whelan TJ, Pignol JP, Levine MN i wsp. Long-term results of hypofractionated radiation therapy for breast cancer. NEnglJMed 2010; 362: 513-520.

7. Wełnicka-Jaśkiewicz M. Zalecenia dotyczące uzupełniającego leczenia chorych na wczesnego raka piersi. Sprawozdanie z 13. Międzynarodowej Konferencji w St. Gallen. Nowotwory J Oncol 2013; 63: 432-435.

8. Gałecki J, Hliniak A, Bujko K i wsp. Wczesne wyniki pooperacyjnej radioterapii w skróconym czasie u chorych na raka piersi - badanie populacyjne. Nowotwory J Oncol 2007; 57: 20-28.

9. Bartelink $\mathrm{H}$, Horiot JC, Poortmans $\mathrm{P}$ i wsp. Impact of a higher radiation dose on local control and survival in breast-conserving therapy of early breast cancer: 10-year results of the randomized boost versus no boost EORTC 22881-10882 trial. J Clin Oncol 2007; 25: 3259-3265.

10. Hurkmans C. Radiation therapy using a simultaneously integrated boost for early-stage breast cancer. Future Oncol 2007 3 : 509-513.

11. Van der Laan HP, Dolsma WV, Maduro JH i wsp. Three-dimensiona conformal simultaneously integrated boost technique for breast-conserving radiotherapy. Int J Radiat Oncol Biol Phys 2007; 68: 1018-1023.

12. Van der Laan HP, Dolsma WV, Schilstra Ci iwsp. Limited benefit of inversely optimised intensity modulation in breast conserving radiotherapy with simultaneously integrated boost. Radiother Oncol 2010; 94: 307-312.

13. Coles CE, Brunt AM, Wheatley D i wsp. Breast radiotherapy: less is more? Clinical Oncology 2013; 25: 127-134.

14. Freedman GM, White JR, Arthur DW i wsp. Accelerated fractionation with a concurrent boost for early stage breast cancer. Radiother Oncol 2013; 106: 15-20.

15. Cante D, Rosa La Porta M, Casanova-Borca V i wsp. Accelerated hypofractionated adjuvant whole breast radiotherapy with concomitant photon boost after conserving surgery for early stage breast cancer: a prospective evaluation on 463 patients. Breast J 2011; 17: 586-593. 